\title{
Constraints Faced by the Rural Youth in Farm Activities
}

\author{
V. Shanjeevika ${ }^{1}$, K. Indumathy ${ }^{2}$ and P.P. Murugan ${ }^{3}$
}

\begin{abstract}
Rural areas are the economic backbone of the country and contribute to the economic growth for development of other sectors. Major portion of the rural population depends on agriculture for their income. In recent years the participation of rural youth in agriculture is declining. This is due to the constraints faced by them and migration to urban areas. A study was conducted in nine villages of Vaniyambadi taluk in Tamil Nadu to assess the constraints faced by rural youth in farm activities. The primary constraint faced by rural youth was lack of technical skills from resource persons, fear of external constraints like pests \& disease followed by difficulty in accessing financial resources, low income generation and lack of proper marketing facilities. Suggestions to overcome the constraints and methods to attract rural youth towards agriculture are also provided.
\end{abstract}

Keywords : Rural youth; Constraints; Farm activities;Tamil Nadu.

Farm youth are the precious asset which have an important role in developmental agricultural activities. If the talents and abilities of them are properly nurtured and guided, agriculture will attain sustainable growth. But the participation and interest of the rural youth towards agriculture is in declining phase in the recent years. This is because of the constraints faced by them in farm activities and also migration to urban areas. Though involvement and participation of youth in agriculture is necessary for economic development of a country the constraints faced by the youth are poorly understood in India. Therefore to address this gap this study aims to assess the constraints faced by rural youth in farm activities.

\section{METHODOLOGY}

From 20 blocks of Vellore district in Tamil Nadu, Alangayam block was selected for the study at random. Among the nine taluks, Vaniyambadi Taluk was selected and among the 32 revenue villages of Vaniyambadi Taluk, nine villages were selected at random. In each village, 10 rural youths were identified based on random sampling method to make 90 respondents. Data collection was done primarily through interviews with wellstructured interview schedule. Constraints

1. PG Scholar, \& 3. Professor and Head, Department of Agricultural Extension and Rural Sociology, AC \& RI, Madurai- 625104 and 2. Assistant Professor, Department of Agricultural Extension and Rural Sociology, Adhiparasakthi Agricultural College, G.B.Nagar, Kalavai-632 506, Vellore dt. 
refer to all the hindrances expressed by respondent in farm activities. The respondents were asked to score for the constraints. If the respondent faces the constraint, a score of two was given and if he does not face a particular constraint a score of 1 was given. Mean and percentage analysis were the statistical tools used for the study.

\section{FINDINGS AND DISCUSSION}

The constraints faced by rural youth are given in Table 1.

Table 1.

\section{Constraints of Rural youth Participation in Farm activities}

$\mathrm{n}=90$

\begin{tabular}{|c|l|c|c|c|}
\hline SI.No & \multicolumn{1}{|c|}{ Constraints } & Mean & Percentage & Rank \\
\hline 1. & $\begin{array}{l}\text { Lack of technical skill support from resource } \\
\text { persons }\end{array}$ & 1.92 & $92.20 \%$ & I \\
\hline 2. & Fear of external constraints like pest, disease & 1.92 & $92.20 \%$ & I \\
\hline 3. & Low income generation & 1.88 & $88.88 \%$ & II \\
\hline 4. & Difficulty in accessing financial resources & 1.88 & $88.88 \%$ & II \\
\hline 5. & Lack of proper marketing facility & 1.86 & $86.66 \%$ & III \\
\hline 6. & $\begin{array}{l}\text { Lack of information about latest schemes and } \\
\text { services in agriculture }\end{array}$ & 1.83 & $83.30 \%$ & IV \\
\hline 7. & Non availability of quality inputs & 1.83 & $83.30 \%$ & IV \\
\hline 8. & Poor government commitment & 1.82 & $81.11 \%$ & $\mathrm{~V}$ \\
\hline 9. & Inadequate irrigation facility & 1.81 & $81.10 \%$ & $\mathrm{VI}$ \\
\hline 10. & Monsoon failure & 1.80 & $80.00 \%$ & $\mathrm{VII}$ \\
\hline 11. & Lack of awareness about important practices & 1.77 & $77.70 \%$ & $\mathrm{VIII}$ \\
\hline
\end{tabular}

It is understood from Table 1 that the major constraints are Lack of technical skills from resource persons and fear of pest and disease. Low income generation was felt as a constraint by $88.8 \%$ of the rural youth as they undergo various risks in farming. The rural youth need to be trained to overcome those risks for better income generation. Difficulty in accessing financial resources was also felt as a constraint by $88.8 \%$ percentage of rural youth.
Based on the results of the study the following suggestions are made.

- Agricultural colleges should concentrate more towards attracting rural youth towards agriculture.

- Government should establish technical and vocational institutes in villages for training the rural youth.

- Agriculture should be included in school curriculum. 
- Youth cherish technology. Hence, ICT can be used to solve the problems and give recommendations to youth.

- Proper technical guidance should be provided to overcome and withstand risks.

- Youth should be assisted to have better access to necessary inputs.

- Location specific trainings for pest and disease eradication should be given by the extension agents.

- Location specific certificate courses can be offered

- Proper marketing facilities need to be created in rural areas so that farmers may get maximum return of their produce.

\section{REFERENCES}

Dhillon, D.S. \& Hansra, B. S. (1995). People's participation in rural development programmes. Kurukshetra, 43(4):7-9

Janani, S., Ravichandran, V \& Sujeetha, T.N. (2016), A Study on marketing behavior of Rural youth entrepreneurs among seven different ventures, Journal of Extension Education, 28(1). 